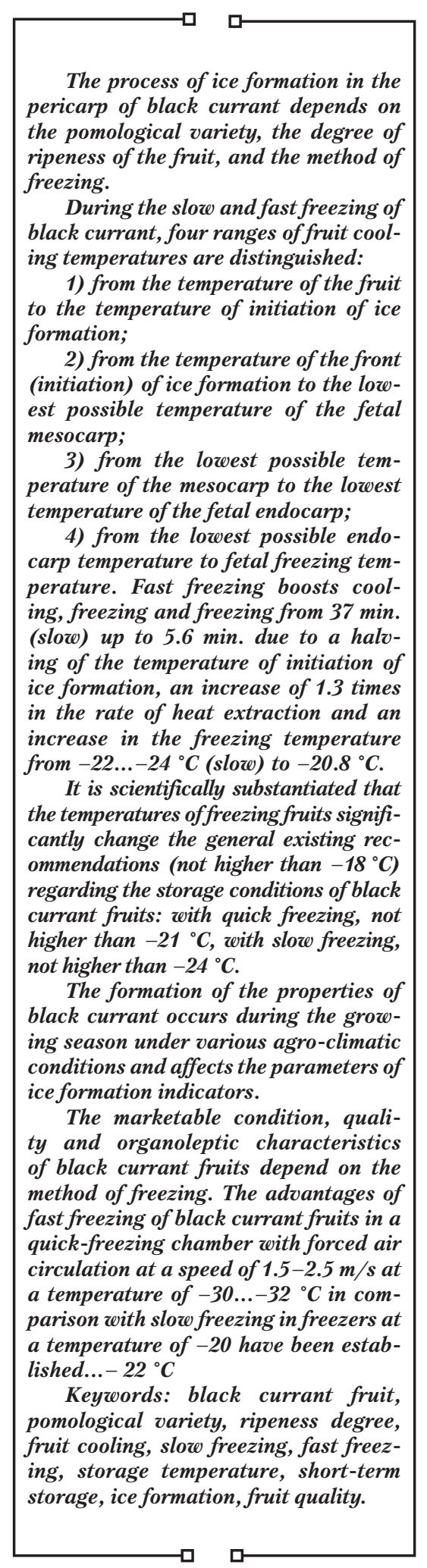

UDC 664.8.037:634.723

DOI: $10.15587 / 1729-4061.2021 .230139$

\section{DEVELOPMENT OF TEMPERATURE REGIME OF STORAGE OF FROZEN BLACK CURRANTS}

Nina Osokina

Doctor of Agricultural Sciences, Professor*

E-mail: ninaosokina1953@gmail.com

Kateryna Kostetska

$\mathrm{PhD}$, Associate Professor*

E-mail: kostetskakateryna@gmail.com

O len a Herasym chuk

$\mathrm{PhD}$, Associate Professor*

E-mail: elena.gerasim4uk@ukr.net

Hennadi i Tkachenko*

E-mail: tkachenkogenady@ukr.net

Hryhori Podpriatov

PhD, Professor

Department of Storage, Processing and Standardization of

Plant Products after prof. B. V. Lesik

National University of Life and Environmental Sciences of Ukraine

Heroyiv Oborony str., 13, Kyiv, Ukraine, 03041

E-mail: podpratovg@gmail.com

L ud mila Pusik

Doctor of Agricultural Sciences, Professor

Department of Optimization of Technological Systems

named after T. P. Yevsyukova

Kharkiv Petro Vasylenko National Technical University of Agriculture Alchevskykh str., 44, Kharkiv, Ukraine, 61002

E-mail: ludapusik@gmail.com

Nataliy Falendysh $\mathrm{PhD}$, Associate Professor**

E-mail: falen@nash.net.ua

In na Bobe I

$\mathrm{PhD}$, Associate Professor** E-mail: Inna_3@ukr.net

Kristina Belinska

$\mathrm{PhD}$

Department of Tourism and Hotel and Restaurant Business Kamianets-Podilskyi National Ivan Ohiienko University Suvorova str., 52, Kamianets Podilskyi, Ukraine, 32300 E-mail: kristina0612@ukr.net *Department of Technology of Storage and Processing of Grain Uman National University of Horticulture Instytutska str., 1, Uman, Ukraine, 20300 **Department of Bakery and Confectionery Goods Technologies National University of Food Technologies Volodymyrska str., 68, Kyiv, Ukraine, 01601
Received date 02.03.2021

Accepted date 19.04.2021 Published date 30.04.2021
How to Cite: Osokina, N., Kostetska, K., Herasymchuk, O., Tkachenko, H., Podpriatov, H., Pusik, L., Falendysh, N., Bobel, I., Belinska, K. (2021). Development of temperature regime of storage of frozen black currants. Eastern-European Journal of Enterprise Technologies, 2 (11 (110)), 33-40. doi: https://doi.org/10.15587/1729-4061.2021.230139

\section{Introduction}

In modern environmental conditions, it is urgent to solve the problem of year-round provision of the population with healing fruits of black currant due to their sufficient production and the use of a highly effective method of canning - freezing.

The nature of ice formation in fruits determines the temperature and freezing rate, which depend on the chemical 
composition of the fruit. The higher the concentration of substances, the greater the resistance of cells to the effects of negative temperatures, the fruits better preserve their natural properties [1,2].

Freezing is accompanied by a deep decrease in the temperature of the fruit and the transformation of moisture into ice, that is, dehydration. The formation of ice crystals causes changes in the tissue structure of the product, the degree of which depends on the freezing speed [3]. By slow freezing of fruits at relatively high temperatures $\left(-4 \ldots-8{ }^{\circ} \mathrm{C}\right)$, ice crystals are formed primarily in the intercellular spaces. In the middle of the cells, where the concentration of juice is higher, ice forms more slowly. The formation of ice crystals and the associated increase in the concentration of sap in the intercellular spaces leads to an increase in osmotic pressure. The water from the cells passes into the intercellular space, where it freezes on the edges of the previously formed crystals. In this case, the cells are dehydrated, and large crystals are formed in the intercellular spaces, unevenly distributed in the tissues. Crystals press on neighboring cells and cause damage to the cell membranes and their death. When the fruits are thawed, the formed moisture does not have time to be absorbed, the juice flows out, the product loses its natural properties: it changes its consistency, becomes watery.

Rapid freezing (temperatures $-35 \ldots-40{ }^{\circ} \mathrm{C}$ and below) does not cause significant deformation of the tissue structure. The cooling rate of the fruit increases sharply, ice crystals are formed simultaneously in the intercellular spaces and in the cells. Removal of moisture from the latter does not work. The faster the process is carried out, the more crystals are formed and their size is smaller. Crystals are evenly distributed in cells and tissues, do not cause significant damage to cell membranes. When these fruits are thawed, more cells bind moisture, the loss of cell juice is not so significant.

The practical implementation of the method of freezing food using liquid nitrogen intensifies the process tens of times $[1,2]$. However, the American firm "Rich Products Corp" has developed and actively developed a technology for freezing drinks, juices, sauces, soups, dough, flour, confectionery and fruits on the principle that free water does not crystallize, but is transferred into a bound state with the components of the chemical composition. Products are usually cooled to $-18{ }^{\circ} \mathrm{C}$ and stored at the same temperature. This method of freezing allows to maintain a soft consistency of the product, which does not require defrosting before use [3, 4].

So, proceeding from the classical assertion that freezing is a phase transition associated with the formation of ice in biological objects, it is clear that the implementation of the process of crystallization of water in frozen materials in compliance with optimal conditions, prevention of cryogenic plant cell structures is the main factor in obtaining frozen fruits and berries of high biological and consumer quality.

\section{Literature review and problem statement}

A brief review of the literature is given [1], reveals the effect of negative temperatures on the microstructure of a plant cell. By slow freezing of fruit pieces, cell division in the parenchymal tissue is observed. The ice that forms in the intercellular spaces pushes the cells apart, causing the lamellae and cell walls to rupture. It has been shown [2] that with an increase in the freezing rate, the deformation and division of cells decreases. Freezing whole fruits, with an average speed and gradual defrosting, causes the least disorganization and fragmentation of protoplasm. Endoplasmic reticulum, ribosomes, Golgi bodies, osmophilic globules, and mitochondria undergo profound changes in fruits with highly vacuolated cells. In work [2], the researchers came to the conclusion that the destruction of membranes with the following losses of cells of the ability to retain water is the main cause of profound structural changes in succulent plant tissues. To prevent weakening of the tissue structure, the duration of freezing should not exceed 30 minutes.

It is shown [3] that a high degree of preservation of the nutritional value and organoleptic properties of frozen fruits and berries is based on the inhibition of biochemical processes and the vital activity of microflora. Microorganisms can develop at temperatures above $-5 \ldots-8{ }^{\circ} \mathrm{C}$, and yeast: $-10 \ldots-12{ }^{\circ} \mathrm{C}$, molds: $-12 \ldots-15{ }^{\circ} \mathrm{C}$ [4].

The work [5] presents the results of histological studies of frozen plant objects. Changes in their structure depend on the structural features of the tissues. The structure of smallcelled tissues (epidermis, core) with tightly adjacent cells is better preserved.

In frozen strawberries, the peel is most resistant to negative temperatures, which consists of small, tightly adjacent cells. The cells of the cortical layer experience more structural changes [5].

By quickly freezing tomatoes in liquid nitrogen $\left(-195^{\circ} \mathrm{C}\right)$, damage to the cells of the epidermis and pulp does not occur; cuticle, epidermal cells, fruit pulp do not separate, and after thawing they are close to fresh. Freezing tomatoes in air $\left(-30{ }^{\circ} \mathrm{C}\right)$ causes damage to the pulp cells. Slow freezing for many hours leads to a thickening of the plates that bind cells and the formation of extracellular ice [3].

Cryoprotectants (protein, salt, sugar) have a positive effect on the quality of frozen fruits and berries and on the integrity of the tissue structure [6].

When freezing raspberries in liquid nitrogen, carbon dioxide, at a temperature of $-25^{\circ} \mathrm{C}$, the internal, external microstructure of the drupe is fully preserved only for the first two methods [6].

The results of studies of the lipid-protein complex [4] and the fractional composition of carbohydrates [7] in grapes responsible for the tissue structure revealed that freezing insignificantly affects the qualitative composition of lipids in the peel and pulp of berries, as a result of which the structure of cell membranes remains intact.

Freezing plum fruits down to $-18{ }^{\circ} \mathrm{C}$ and $-40{ }^{\circ} \mathrm{C}$ is not accompanied by rupture of cell membranes or damage to plasmodesmata. Least of all are subject to changes in mitochondria and nucleus. Plastids are rearranged into a state of destruction, starch grains remain intact. Freezing to $-40{ }^{\circ} \mathrm{C}$ causes an increase in vesicles by $5-8$ times. This is evidence of the continuation of the process of freezing of moisture, the formation of a more compact ice system, which aligns the vesicles in the cut plane to the shape of a circle [8].

In thawed fruits of apples, pears, plums, the epidermis exfoliates from the pulp, the hypodermis stratifies, the cells of the main parenchyma are severely deformed, their cell walls are mostly destroyed [9].

The softening of fruits during storage occurs due to genetically determined disintegration of the glycosylprotein complex of cell walls, increased degradation of pectin polysaccharides in the middle plate, and a decrease in calcium content in cell membranes. The transformation of pectins with the formation of calcium pectinates is considered to be 
the reason for the hardening of the structure of frozen cherries and cherries [10].

So, bioproducts during freezing are adversely affected by ice crystals, excessive dehydration, hyperconcentration of salts, and other changes in $\mathrm{pH}$ [11]. The study of the role of each of these factors in cryo-sensitization of cells and tissues has led to the emergence of numerous concepts and hypotheses that interpret differently the mechanism of action of one or another damaging factor and its role in the destruction of biological object structures during freezing. In the damage to cells caused by crystallization, in the early stages of research, the focus is on extracellular ice. However, the inconsistency of the results and conclusions regarding its role remains unclear until now [11-13]. Further studies have shown that ice crystals can form not only in the intercellular space, but also in the middle of cells $[14,15]$.

From the above review of literary sources, it is clear that for all biological objects, including fruit and berry raw materials, there is one regularity - when cooled to $0{ }^{\circ} \mathrm{C}$ and below, under the influence of negative temperatures, cells can be destroyed. All this

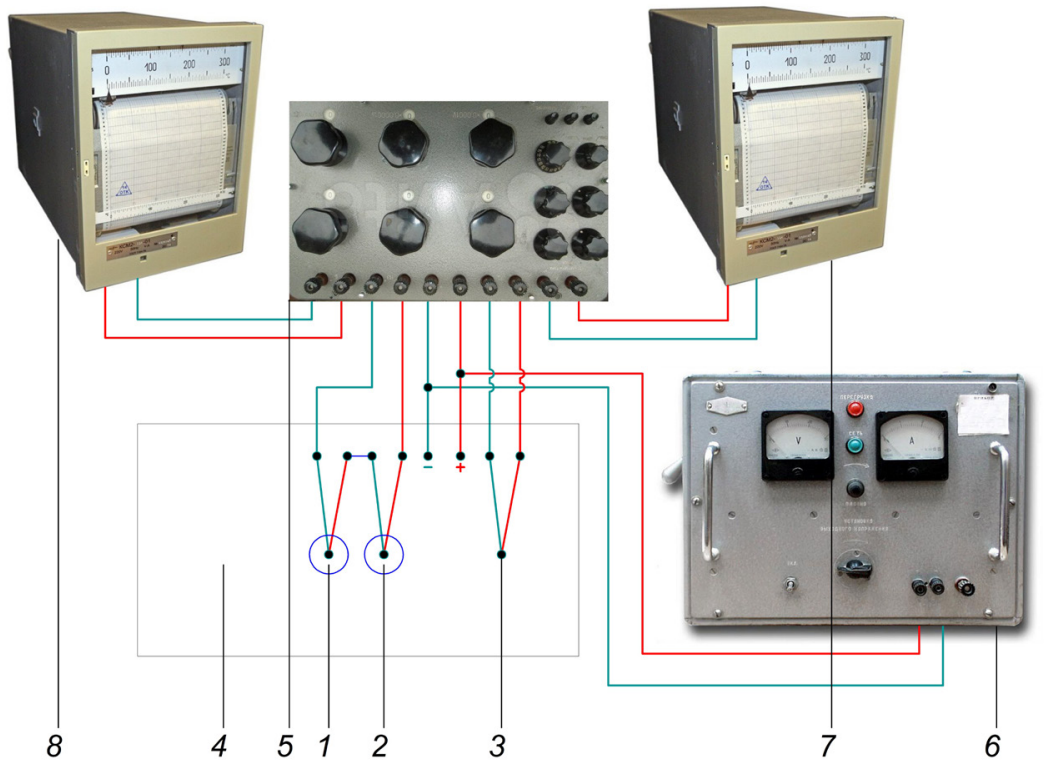

Fig. 1. Schematic diagram of the differential thermal analysis setup: 1 - sample with a thermocouple; 2 - standard with a thermocouple; 3 - thermocouple for recording the temperature in the chamber of microrefrigerators; 4 - micro-refrigerators TLM-2 (USSR); 5 - two-coordinate potentiometer R-307 (Russia, Krasnodar); 6 - power supply unit for microrefrigerators VSP-33 (USSR, Lviv); 7, 8 - paper recorder (USSR, Lviv) gives grounds to assert that it is expedient to conduct a study of the ice formation process in black currant fruits, depending on the freezing method, pomological variety, degree of ripeness and short-term storage. During freezing, structural changes occur in the food [1]. Literature sources do not give a complete picture of the nature and characteristics of such changes in fruits and berries, therefore, their research remains relevant and requires a solution.

\section{The aim and objectives of research}

The aim of research is to establish the temperature regime of storage of frozen black currant fruits of different pomological variety, degree of ripeness, method of freezing with the study of the ice formation process.

To achieve this aim let's solve the problem:

- to study the duration and process of cooling and phase transitions of cell juice into ice depending on the pomological variety, degree of ripeness and short-term storage of black currant fruits;

- to carry out a comparative assessment of slow and fast freezing by changing the parameters of the ice formation process in blackcurrant fruits and to establish a rational way of freezing blackcurrant fruits and their storage temperature.

\section{Materials and methods of research}

The fruits of black currant varieties Bilorus Sweet, Minai Shmyrev, which were used in the study, were grown on the experimental field of the educational and production department of the Uman National University of Horticulture.

The assessment of the ice formation process was carried out according to the modern method of differential thermal analysis (DTA) [16] using a specially created device [16] for plant objects (Fig. 1).

The DTA method [16] of plant objects provides for the analysis of thermograms of ice formation taking into account the ratio of individual bands and the interval of their appearance [8].

Chromel-Alumel thermocouples were used as temperature sensors. One thermocouple was introduced into the central part of the fetus, the other into the reference sample. Paraffin was used as an indifferent standard in size, which was close to the size of the sample. The thermocouples were turned on with their poles facing each other. The signal was applied to the "Y" input of a highly sensitive potentiometer R-307 with two coordinates. Another thermocouple was used to measure the temperature in the cooler chamber. The signal from this thermocouple was fed to the " $\mathrm{X}$ " input of the same potentiometer.

During the analysis, the samples were cooled in a twostage semiconductor microcooler of the TLM-2 type. The temperature in the chamber was reduced at a constant rate of $1{ }^{\circ} \mathrm{C} / \mathrm{min}$. in the temperature range $+10 \ldots-40{ }^{\circ} \mathrm{C}$. Connecting thermocouples allows to measure the temperature difference between the sample and the standard during ice formation. When water is converted into ice, latent heat is released, which is measured as the difference in signals from thermocouples caused by an increase in the temperature of the sample under study relative to the standard, does not contain water.

Ice formation in various tissues of the sample proceeded unevenly, therefore, on the exotherms there are several maxima, the amplitude, the position of which was determined by the water-physical properties of the tissues. The exotherm was registered on a sheet of graph paper, marked for further processing of the results. They were brought to a computer in a database that was created on the basis of the Excel program of the Windows operating system.

The anatomical structure of the pericarp of black currant was studied using a microscope "Lomo Biol- 
am” S1U4.2 (Russia, St. Petersburg), preliminarily performing sections of microtome MZ-1 (Russia, St. Petersburg) with the device TOS-2 (USSR). The images of the sections were recorded on a computer using a Philips ToUcam camera video attachment (Netherlands) and a special system for microscopy and analysis "Image Scope Lite" (according to the method [17]).

\subsection{Experimental procedures}

The research was carried out in the laboratory of the Department of Storage Technology and Processing of Plant Growing Products and the Quick Freezing Shop of the Uman Cannery (Ukraine) in accordance with the "Methodological Guidelines for Conducting Research on Quick Frozen Fruits, Berries and Vegetables" [18].

Fruits of black currant of a consumer degree of ripeness were harvested under favorable weather conditions, berries without brushes were selected according to GOST 6829-89, in boxes-trays No. 5.2 weighing $4-5 \mathrm{~kg}$. They were transported to the laboratory and the quick-freezing shops. After inspection, washing, water removal on filter paper, re-inspection, the fruits were packed in mesh bags with a capacity of 400-500 g (control), weighed, frozen according to the following experiment options:

- slow freezing in freezers "Calex" (Slovakia) at a temperature of $-20 \ldots-22^{\circ} \mathrm{C}$;

- fast freezing in a fast freezing chamber with forced air circulation at a speed of $1.5-2.5 \mathrm{~m} / \mathrm{s}$ at a temperature of $-30 \ldots-32{ }^{\circ} \mathrm{C}$.

After weighing, the fruits were packed in plastic bags ( $50-55$ microns thick) weighing 400-500 g, and sealed. The bags were stored at a temperature not exceeding $-18{ }^{\circ} \mathrm{C}$.

\section{Research results of the ice formation process in the fruits of ice formation}

5. 1. Duration and process of cooling and phase transitions of cell sap into ice, depending on the pomological variety, ripeness degree and short-term storage of black currant fruits

Fig. 2, 3 show typical changes during ice formation in fruits, characterizing the phase transition of a liquid into a solid.

The results of the exothermic process converted into digital form are reflected in Tables 1, 2.

Ice formation in whole fruits is reflected by a rather diffuse spectrum of the exothermic process in a wide temperature range: $-6.2 \ldots-24.3^{\circ} \mathrm{C}$. At the same time, the spectra of the exothermic process almost always have two large bands in the temperature range: the first: $-6.2 \ldots-9.0{ }^{\circ} \mathrm{C}$; the second: $-9 \ldots-24.3^{\circ} \mathrm{C}$. Obviously, the first exotherm characterizes the processes of ice formation in the tissues of the mesocarp, the second - in the tissues of the fetal endocarp. Against their background, there is still a small low-temperature exotherm in the range of $-16.9 \ldots-24.3{ }^{\circ} \mathrm{C}$. Its occurrence can be associated with ice formation in the cells of the fetal endocarp.

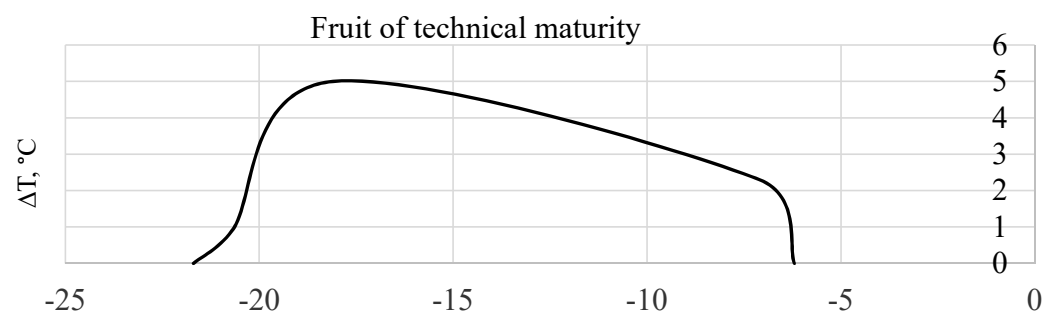

Cooling temperature, ${ }^{\circ} \mathrm{C}$

$a$

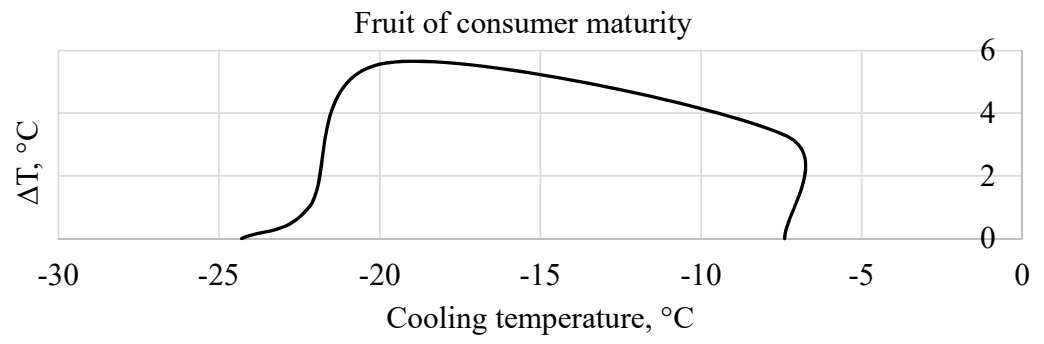

b

Fig. 2. Thermograms of ice formation in black currant fruits of the Bilorus Sweet variety depending on the phase of ripeness for slow freezing: $a-$ fruits of a technical ripeness degree; $b$ - fruits of the consumer's foot of ripeness

Fruit of technical maturuty

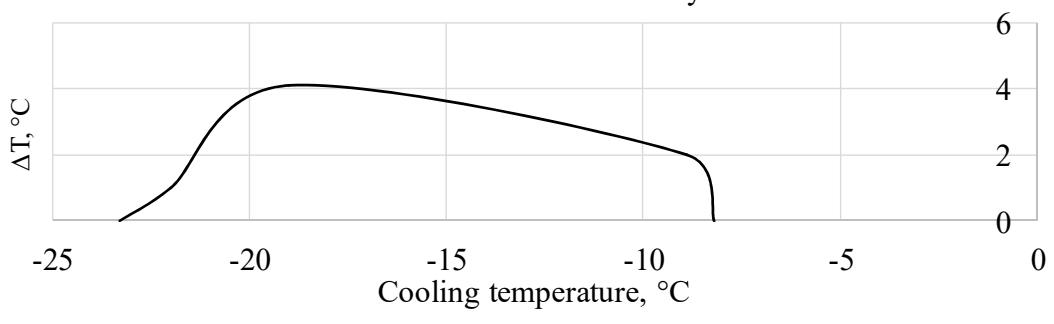

Fruit of consumer maturity

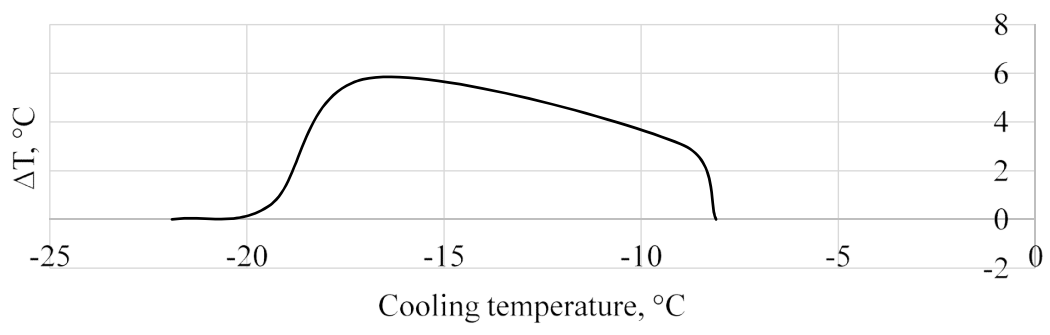

b

Fig. 3. Thermograms of ice formation in black currant fruits of the Minai Shmyrev variety, depending on the ripeness phase for slow freezing: $a-$ fruits of a technical degree of ripeness; $b-$ the fruits of the consumer's foot of ripeness 
Table 1

Changes in the parameters of indicators of the ice formation process in black currant fruits by slow freezing

\begin{tabular}{|c|c|c|c|c|c|c|c|c|}
\hline \multirow{3}{*}{ Grade } & \multirow{3}{*}{ Fruit condition } & \multicolumn{7}{|c|}{ DTA indicators, ${ }^{\circ} \mathrm{C}$} \\
\hline & & \multicolumn{4}{|c|}{ temperature } & \multicolumn{3}{|c|}{ amplitude } \\
\hline & & front & $\begin{array}{l}\text { maximum } \\
\text { mesocarp }\end{array}$ & $\begin{array}{l}\text { maximum } \\
\text { endocarp }\end{array}$ & LTE & $\Delta T$ mesocarp & $\Delta T$ endocarp & $\triangle T L T E$ \\
\hline Bilorus Sweet & \multirow{2}{*}{ technical ripeness } & -6.2 & -7.1 & -18.1 & $-20.7 \ldots-21.7$ & 2.3 & 5.0 & 0.1 \\
\hline Minai Shmyrev & & -8.2 & -8.9 & -19.0 & $-22.0 \ldots-23.3$ & 2.0 & 4.1 & 0.1 \\
\hline Bilorus Sweet & \multirow{2}{*}{ consumed ripeness } & -7.4 & -7.4 & -19.8 & $-22.2 \ldots-24.3$ & 3.3 & 5.6 & 0.1 \\
\hline Minai Shmyrev & & -8.1 & -9.0 & -16.9 & $-19.4 \ldots-21.9$ & 3.1 & 5.8 & 0.2 \\
\hline
\end{tabular}

Table 2

Changes in the parameters of indicators of the ice formation process in black currant fruits of a consumer degree of ripeness by quick freezing

\begin{tabular}{|c|c|c|c|c|c|c|c|c|}
\hline \multirow{3}{*}{ Grade } & \multirow{3}{*}{ Fruit condition } & \multicolumn{7}{|c|}{ DTA indicators, ${ }^{\circ} \mathrm{C}$} \\
\hline & & \multicolumn{4}{|c|}{ temperature } & \multicolumn{3}{|c|}{ amplitude } \\
\hline & & front & $\begin{array}{l}\text { maximum } \\
\text { mesocarp }\end{array}$ & $\begin{array}{l}\text { maximum } \\
\text { endocarp }\end{array}$ & LTE & $\begin{array}{l}\Delta T \text { meso- } \\
\text { carp }\end{array}$ & $\begin{array}{l}\Delta T \text { endo- } \\
\text { carp }\end{array}$ & $\triangle T L T E$ \\
\hline Bilorus Sweet & \multirow{2}{*}{ before storage } & -15.7 & -16.0 & -17.6 & $-20.0 \ldots-20.8$ & 4.2 & 4.6 & 0.1 \\
\hline Minai Shmyrev & & -15.8 & -16.2 & -17.9 & $-20.0 \ldots-20.8$ & 3.8 & 4.2 & 0.1 \\
\hline Bilorus Sweet & \multirow{2}{*}{ after storage } & -14.8 & -15.4 & -18.2 & $-21.8 \ldots-23.0$ & 3.4 & 5.2 & 0.2 \\
\hline Minai Shmyrev & & -13.9 & -14.9 & -17.2 & $-21.0 \ldots-22.0$ & 3.2 & 4.9 & 0.1 \\
\hline
\end{tabular}

Ice formation in whole fruits is reflected by a rather diffuse spectrum of the exothermic process in a wide temperature range: $-6.2 \ldots-24.3^{\circ} \mathrm{C}$. At the same time, the spectra of the exothermic process almost always have two large bands in the temperature range: the first: $-6.2 \ldots-9.0^{\circ} \mathrm{C}$; the second: $-9 \ldots-24.3^{\circ} \mathrm{C}$. Obviously, the first exotherm characterizes the processes of ice formation in the tissues of the mesocarp, the second - in the tissues of the fetal endocarp. Against their background, there is still a small low-temperature exotherm in the range of $-16.9 \ldots-24.3^{\circ} \mathrm{C}$. Its occur- rence can be associated with ice formation in the cells of the fetal endocarp.

5. 2. Comparative evaluation of the method of freezing by changing the parameters of indicators of the process of ice formation

Fig. 4 shows thermograms of ice formation in fruits of black currant varieties Bilorus Sweet for quick freezing.

Fig. 5 shows thermograms of ice formation in fruits of black currant variety Minai Shmyrev for fast freezing.

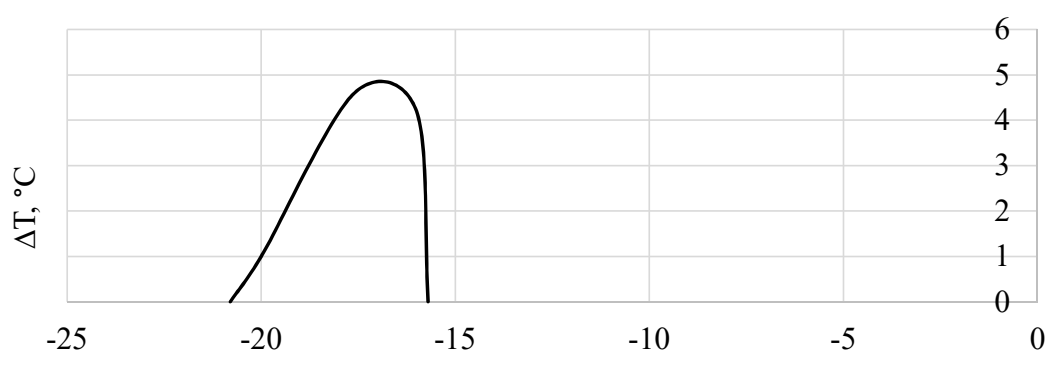

Cooling temperature, ${ }^{\circ} \mathrm{C}$

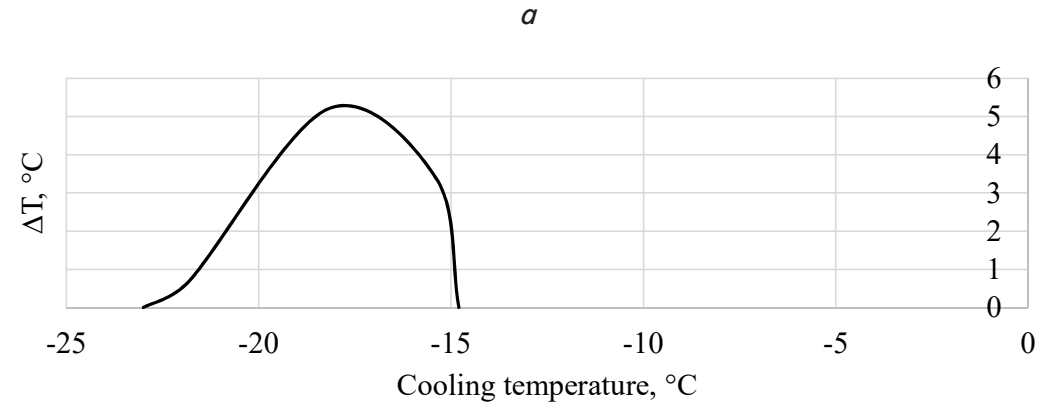

$b$

Fig. 4. Thermograms of ice formation in the fruits of black currant varieties Bilorus Sweet consumer degree of ripeness for quick freezing: $a-$ immediately after freezing; $b$ - after short-term storage in the refrigerator 


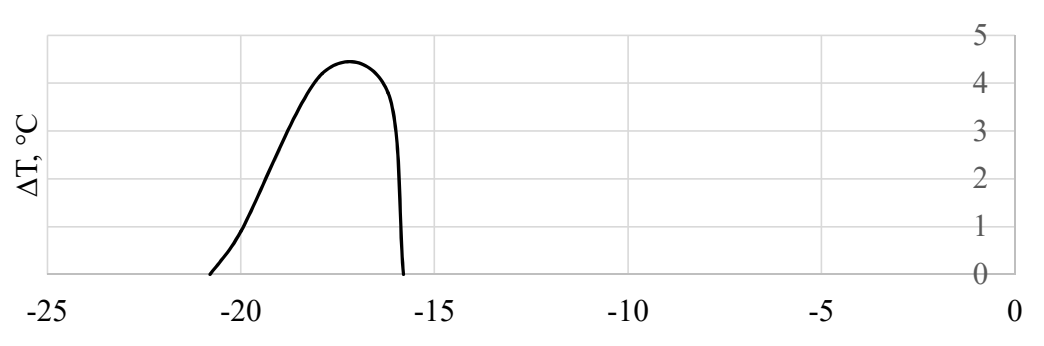

Cooling temperature, ${ }^{\circ} \mathrm{C}$ a

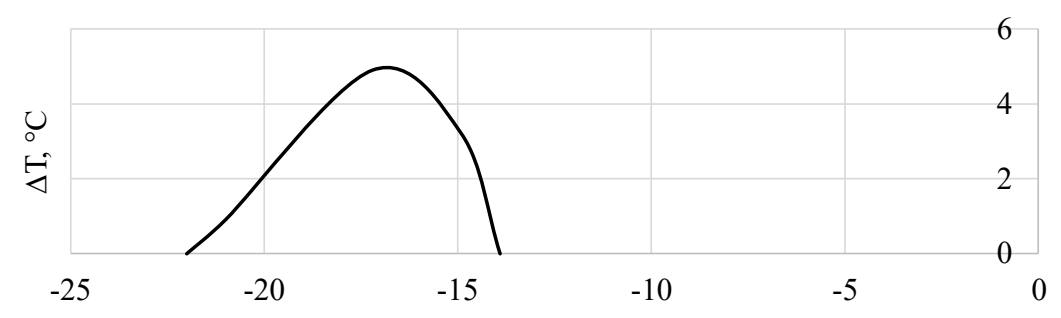

Cooling temperature, ${ }^{\circ} \mathrm{C}$

$b$

Fig. 5. Thermograms of ice formation in black currant fruits of the Minai Shmyrev variety of consumer degree of ripeness for quick freezing: $a-$ immediately after freezing; $b-$ after short-term storage in the refrigerator

The process of ice formation depends on the degree of ripeness of the fruit and the pomological variety. With an increase in the concentration of organic substances in the juice of ripe fruits (the content of dry soluble substances is $15.9 \%$, versus $13.7 \%$ in fruits of the technical degree of ripeness), the temperature of initiation of ice formation $\left(-7.4^{\circ} \mathrm{C}\right)$ in the mesocarp of the fruit of the Bilorus Sweet variety decreases...In the fruits of the Minai Shmyrev variety, such a pattern was not always manifested, however, the indicated temperatures were lower $--8.1 \ldots-9.0{ }^{\circ} \mathrm{C}$. Ice formation in the endocarp was observed at temperatures of $-17 \ldots-20^{\circ} \mathrm{C}$ (ripe fruits) and $-18 \ldots-19{ }^{\circ} \mathrm{C}$ (brown fruits). The indicator of the exothermic process in the mesocarp did not depend on the variety and was $3.1 \ldots 3.3{ }^{\circ} \mathrm{C}$ for ripe fruits, $2.0 \ldots 2.3^{\circ} \mathrm{C}$ for brown fruits. Accordingly, the indicator of the exothermic process increased in the endocarp to $5.6 \ldots 5.8^{\circ} \mathrm{C}$ and $4.1 \ldots 5.0^{\circ} \mathrm{C}$.

\section{Discussion of the research results of the freezing effect on the quality of black currant fruits}

Analysis of thermograms indicates the presence of high-temperature exotherms (HTE) associated with ice formation in the mesocarp and low-temperature exotherms (HTE) - in the endocarp of the fetus. But on the thermograms, the high-temperature maximum of the exothermic transition is significantly modified, as a result of which the clear high-temperature exothermic transition disappears. This is probably due to the anatomical structure of the fetus. The juicy part of the black currant fruit is formed mainly by arillus - formations, represented by strands of pectin mucus.

When freezing, the speed of the process is of decisive importance. A close relationship has been established between the quality of the product and the speed of the process. Ex- perimental data $[19,20]$ indicate the effect of the freezing rate on the size of ice crystals, structural changes in products. The idea of fast ("shock") freezing is to speed up the processes of cooling, freezing and freezing food. This is achieved by increasing the rate of heat extraction in products by lowering the temperature of the environment to $-27 \ldots-35^{\circ} \mathrm{C}$ and by accelerating the movement of the coolant (air) by intensive blowing (Table 2). A decrease in temperature leads to unjustified expenditure of power and an increase in product deformation, the unevenness of the process becomes too large.

The changes that took place in the fruits of the black currant after quick freezing did not depend on the variety. Rapid freezing of fruits initiated ice formation at temperatures of about $-15.8{ }^{\circ} \mathrm{C}$ (Table 2), which is 2 times lower than at slow freezing (Table 1). These temperatures were close to the temperatures that caused ice formation in the mesocarp $(-16.0 \ldots-$ $16.2{ }^{\circ} \mathrm{C}$ ). The maximum of the exothermic transition was significantly modified; it is difficult to isolate it in the fruits of the Belorusskaya Sweet variety.

Cooling temperatures caused endocarp ice formation, decreased to $-17.6 \ldots-17.9^{\circ} \mathrm{C}$, which is $2.3^{\circ} \mathrm{C}$ lower than in the mesocarp of the fruit of the Bilorus Sweet variety and $1{ }^{\circ} \mathrm{C}$ lower than in the mesocarp of the fruit varieties Minai Shmyrev.

The indicator of the exothermic process by rapid freezing in the mesocarp of the fetus is higher $\left(3.8 \ldots 4.2^{\circ} \mathrm{C}\right)(\mathrm{Ta}-$ ble 2), then the process is inhibited in the endocarp of the fetus $\left(4,2 \ldots 4,6{ }^{\circ} \mathrm{C}\right)$ with its completion.

Ice formation in currant fruits, short-term stored, is characterized by high temperatures of initiation of the process and the formation of ice in the mesocarp, but lower temperatures in the endocarp. This caused a corresponding decrease in the rate of exothermic process in the mesocarp $\left(3.2 \ldots 3.4^{\circ} \mathrm{C}\right)$ and an increase in the endocarp $\left(4.9 \ldots 5.2^{\circ} \mathrm{C}\right)$ (Fig. 4, 5).

Since the temperature in the chamber decreased at a rate of $1{ }^{\circ} \mathrm{C} / \mathrm{min}$, this made it possible to establish the duration of freezing of black currant fruits. The duration of the process in a ripe fruit for slow freezing is 20 min (Table 1), with fast -2 min (Table 2). The whole process of freezing the fetus was 37 and 5.6 minutes, respectively. Fast freezing is 10 and 6.6 times faster, respectively. In fruits, previously stored in a refrigerator for a short time, for quick freezing, ice formation was completed in 4 minutes, and the entire freezing process - in 8.4 minutes (Fig. 4, 5).

Based on the analysis of experimental data, when freezing black currant, 4 ranges of fruit cooling temperatures can be distinguished:

1) from a fruit temperature of $18{ }^{\circ} \mathrm{C}$ to the temperature of initiation of ice formation $\left(-7.4 \ldots-8.1^{\circ} \mathrm{C}-\right.$ slow, $-15.8^{\circ} \mathrm{C}$ - fast);

2) from the temperature of the front (initiation) of ice formation $\left(-7.4 \ldots-8.1^{\circ} \mathrm{C}-\right.$ slow, $-15.8{ }^{\circ} \mathrm{C}-$ fast) to the lowest possible temperature of the fetal mesocarp $\left(-7.4 \ldots-9.0^{\circ} \mathrm{C}-\right.$ slow, $-16.0 \ldots-16.2{ }^{\circ} \mathrm{C}$ - fast); 
3) from the lowest possible temperature of the mesocarp $\left(-7.4 \ldots-9.0{ }^{\circ} \mathrm{C}-\right.$ for the slow, $-16.0 \ldots-16.2^{\circ} \mathrm{C}-$ fast $)$ to the lowest possible temperature of the endocarp of the fetus $\left(-16.9 \ldots-19.8^{\circ} \mathrm{C}-\right.$ slow, $-17.6 \ldots-17.9^{\circ} \mathrm{C}-$ fast $)$;

4) from the lowest possible endocarp temperature (-16.9...$19.8^{\circ} \mathrm{C}-$ slow, $-17.6 \ldots-17.9^{\circ} \mathrm{C}-$ for fast) to freezing temperature of the fetus $\left(-21.9 \ldots-24.3^{\circ} \mathrm{C}-\right.$ slow, $-20.8{ }^{\circ} \mathrm{C}$ - fast).

At the indicated temperatures in the mesocarp of the fetus, the indicator of the exothermic process reaches $3.1 \ldots 3.3^{\circ} \mathrm{C}$ for a slow one (Table 1 ); $3.8 \ldots 4.2{ }^{\circ} \mathrm{C}$ for quick (Table 2) freezing, in the endocarp of the fetus, respectively $5.6 \ldots 5.8^{\circ} \mathrm{C}$ and $4.2 \ldots 4.6{ }^{\circ} \mathrm{C}$. In the process freezing, the indicator of the exothermic process of fruits decreases to $0.1{ }^{\circ} \mathrm{C}$, fruits acquire temperatures of $-21.9 \ldots-24.3{ }^{\circ} \mathrm{C}$ with slow freezing and $-20.8^{\circ} \mathrm{C}$ with quick freezing.

Analysis of the exothermic process in blackcurrant fruits during freezing provides sufficient information to solve practical technological issues. Recorded temperatures, freezing fruits radically change the recommendations regarding storage conditions for black currant fruits: for quick freezing not higher than $-21^{\circ} \mathrm{C}$ (Table 2), with slow freezing - not higher than $-24^{\circ} \mathrm{C}$ (Table 1 ).

Black currant fruits must be packed in plastic bags (5055 microns thick) weighing 400-500 g, sealed and stored at a temperature not exceeding $-18{ }^{\circ} \mathrm{C}$. The temperature in the chamber must be reduced at a constant rate of $1{ }^{\circ} \mathrm{C} / \mathrm{min}$ in the temperature range $+10 \ldots-40{ }^{\circ} \mathrm{C}$.

The questions of the influence of the established conditions of freezing and storage on weight loss, indicators of cryoresistance (tendency to cracking, loss of juice after defrosting, etc.), changes in the commodity and quality indicators of black currant fruits throughout the year remain unstudied.

\section{Conclusions}

1. The process of ice formation of the pericarp of black currant depends on the pomological variety, the degree of maturity of the fruit, the method of freezing. The microstructure of the peel of fruits of various pomological varieties affects their physical changes. The increase in the intercellular spaces, the thickening of the network of their branches in the peel of the fruits of the Bilorus Sweet variety is reflected in the change in the parameters of ice formation indices in comparison with those in the fruits of the Minai Shmyrev variety. The quality of frozen black currants is determined by the formation of the properties of fruits of technical and consumer ripeness during the growing season in different agroclimatic conditions, affects the components of the integrating indicator of the content of dry soluble substances, which varies from 13.7 to $15.9 \%$ under the influence of weather conditions in typical pomological conditions. After weighing, the fruits should be packed and sealed. It is advisable to store frozen fruits of black currant at a temperature not higher than minus $21^{\circ} \mathrm{C}$ after fast and minus $24^{\circ} \mathrm{C}$ after slow freezing.

2. The advantages of fast freezing of black currant fruits in a quick-freezing chamber with forced air circulation at a speed of $1.5-2.5 \mathrm{~m} / \mathrm{s}$ at a temperature of $-30 \ldots-32{ }^{\circ} \mathrm{C}$ in comparison with slow freezing in freezers "Calex" at a temperature of $-20 \ldots-22{ }^{\circ} \mathrm{C}$. Rapid freezing boosts cooling, freezing and freezing from 37 to 5.6 minutes. due to a halving of the temperature of initiation of ice formation, an increase of 1.3 times in the rate of heat extraction and an increase in the temperature of freezing from $-22 \ldots-24{ }^{\circ} \mathrm{C}$ (slow) to $-20.8^{\circ} \mathrm{C}$.

\section{Acknowledgement}

Sincere gratitude to the researcher of the Institute of Horticulture of the National Academy of Sciences of Ukraine A. Kitaev, with the direct participation of whom, on a device designed by him, a study of the process of ice formation in black currant fruits was carried out.

\section{References}

1. Osokina, N., Kostetska, K., Gerasymchuk, H. (2020). Ascorbic acid in black currant fruits. Collected Works of Uman National University of Horticulture, 1 (97), 82-91. doi: https://doi.org/10.31395/2415-8240-2020-97-1-82-91

2. Yalpachik, V. F. (2005). Novyy metod zamorazhivaniya i razmorazhivaniya. Ovoschevodstvo, 11, 63.

3. Golub, O. V., Poznyakovskiy, V. M., Zharkov, A. S. (2009). Vliyanie zamorozki na kachestvennye pokazateli yagod vishni. Pischevaya promyshlennost', 7, 32-33.

4. Gonçalves, E. M., Abreu, M., Brandão, T. R. S., Silva, C. L. M. (2011). Degradation kinetics of colour, vitamin C and drip loss in frozen broccoli (Brassica oleracea L. ssp. Italica) during storage at isothermal and non-isothermal conditions. International Journal of Refrigeration, 34 (8), 2136-2144. doi: https://doi.org/10.1016/j.ijrefrig.2011.06.006

5. Belinska, S. (2008). Otsinka strukturno-mekhanichnykh vlastyvostei shvydkozamorozhenoi plodoovochevoi produktsiyi. Kharchova ta pererobna promyslovist, 11, 23-25.

6. Bayyar, F. (2000). Novoe v razvitii global'noy holodil'noy tsepi. Holodil'naya tehnika, 7, 13-16.

7. Orlova, N. Ya., Belinska, S. O. (2013). Upravlinnia bezpechnistiu ta yakistiu shvydkozamorozhenoi plodoovochevoi produktsiyi. Kyiv: Kyiv. nats. torh.-ekon. un-t, 196.

8. Debenedetti, P. G. (2003). Supercooled and glassy water. Journal of Physics: Condensed Matter, 15 (45), R1669-R1726. doi: https://doi.org/10.1088/0953-8984/15/45/r01

9. Suutarinen, J., Honkapää, K., Autio, K., Mokkila, M. (2002). The effect of $\mathrm{CaCl}_{2}$ and pme prefreezing treatment in a vacuum on the structure of strawberries. Acta Horticulturae, 567, 783-786. doi: https://doi.org/10.17660/actahortic.2002.567.173

10. Osokina, N., Kostetska, K., Gerasymchuk, H. (2020). Formation of Frozen Blackcurrant Fruits Quality. Annual Research \& Review in Biology, 35 (10), 97-112. doi: https://doi.org/10.9734/arrb/2020/v35i1030295 
11. Minetti, M., Ceccarini, M., Maria, A., Di Stasi, M. (1984). Role of membrane thermotropic properties on hypotonic hemolysis and hypertonic cryohemolysis of human red blood cells. Journal of Cellular Biochemistry, 25 (2), 61-72. doi: https://doi.org/10.1002/ jcb.240250202

12. Nei, T. (1976). Freezing injury to erythrocytes. II. Morphological alterations of cell membranes. Cryobiology, 13 (3), $287-294$. doi: https://doi.org/10.1016/0011-2240(76)90110-3

13. Simakhina, G., Naumenko, N., Bazhaj-Zhezherun, S., Kaminska, S. (2019). Impact of cryoprotection on minimization of ascorbic acid losses in freezing of berries. Ukrainian Food Journal, 8 (2). doi: https://doi.org/10.24263/2304-974x-2019-8-2-7

14. Sousa, M. B., Canet, W., Alvarez, M. D., Tortosa, M. E. (2005). The effect of the pre-treatments and the long and short-term frozen storage on the quality of raspberry (cv. Heritage). European Food Research and Technology, 221 (1-2), 132-144. doi: https://doi.org/ 10.1007/s00217-005-1189-1

15. Paardekooper, M., Van den Broek, P. J. A., De Bruijne, A. W., Elferink, J. G. R., Dubbelman, T. M. A. R., Van Steveninck, J. (1992). Photodynamic treatment of yeast cells with the dye Toluidine blue: all-or-none loss of plasma membrane barrier properties. Biochimica et Biophysica Acta (BBA) - Biomembranes, 1108 (1), 86-90. doi: https://doi.org/10.1016/0005-2736(92)90117-5

16. Makarova, D. H., Kytaiev, O. I. (2003). Zastosuvannia metodu dyferentsiynoho termichnoho analizu dlia doslidzhennia protsesiv lodoutvorennia v riznykh orhanakh plodovykh roslyn. Problemy monitorynhu u sadivnytstvi. Kyiv: Ahrarna nauka, 135-145.

17. Zamorskyi, V. V. (2005). Osoblyvosti metodyky vyvchennia anatomichnoi budovy strukturnykh elementiv derev yabluni z dopomohoiu kompiuternoi tekhniky. Zbirnyk naukovykh prats Umanskoho derzhavnoho ahrarnoho universytetu, 59, 268-270.

18. Metodicheskie ukazaniya po provedeniyu issledovaniy s bystrozamorozhennymi plodami, yagodami i ovoschami (1984). Moscow: VASHNIL, 24.

19. Orlova, N. Ya., Belinska, S. O. (2005). Zamorozheni plodoovochevi produkty: problemy formuvannia asortymentu ta yakosti. Kyiv: Nats. torh.-ekon. un-t, 336.

20. Pavluk, R., Pogarskiy, A., Kaplun, H., Loseva, S. (2015). Developing the cryogenic freezing technology of chlorophyllcontaining vegetables. Eastern-European Journal of Enterprise Technologies, 6 (10 (78)), 42-47. doi: https://doi.org/10.15587/ 1729-4061.2015.56111 